\title{
An Examination of Rhizobium leguminosarum for the Production of Extracellular and Periplasmic Proteins
}

\author{
By A. R. GLENN AND M. J. DILWORTH \\ School of Environmental and Life Sciences, Murdoch University, \\ Murdoch, Western Australia 6153, Australia
}

(Received 12 December 1978)

\begin{abstract}
Rhizobium leguminosarum WU163 and WU235 did not release extracellular proteins into the environment but did synthesize periplasmic proteins, including alkaline phosphatase (EC 3.1.3.1), cyclic phosphodiesterase (EC 3.1.4.d) and inorganic pyrophosphatase (EC 3.6.1.1). Fourteen periplasmic proteins, recognized by polyacrylamide gel electrophoresis, were released by lysozyme/EDTA treatment. Four of these proteins, including the alkaline phosphatase, were repressed by phosphate.
\end{abstract}

\section{INTRODUCTION}

Many bacteria produce extracellular hydrolytic enzymes which degrade large macromolecules or cleave smaller molecules, often producing hexoses or inorganic phosphate $\left(P_{i}\right)$ (Pollock, 1962; Glenn, 1976). Although many of these organisms are Gram-positive, some Gram-negative organisms also secrete proteins into their external environment. In other Gram-negative organisms hydrolytic enzymes may remain associated with the outer cell surface (Hofsten, 1975) or are localized in the periplasm (Cheng et al., 1970; Neu \& Heppel, 1965). These periplasmic proteins may be released from Escherichia coli by osmotic shock or sphaeroplast formation (Neu \& Heppel, 1965; Nossal \& Heppel, 1966).

Little is known about the ability of rhizobia to produce extracellular or periplasmic proteins; such proteins may play some role in the infection process or in saprophytic existence in the soil or rhizosphere. This study was undertaken to determine if Rhizobium leguminosarum produces extracellular or periplasmic proteins and to examine the nature of such proteins.

\section{METHODS}

Organisms. Rhizobium leguminosarum, WU163 and WU235 were from the culture collection of the Institute of Agriculture, University of Western Australia. Both strains nodulate Vicia sativa and Vicia atropurpurea.

Media. Rhizobia were grown in batch culture at $27^{\circ} \mathrm{C}$ in the glutamate/minimal salts medium of Brown \& Dilworth (1975) containing glucose, mannitol or glycerol (each at $2 \cdot 5 \mathrm{~g}^{-1}$ ) as a carbon source. They were also grown in the yeast extract/mannitol broth of Godfrey \& Dilworth (1971).

Enzyme assays. Acid and alkaline $\alpha$-amylase (EC 3.2.1.1) activities were measured using amylose/azure $\left(10 \mathrm{mg} \mathrm{ml}^{-1}\right)$ or the more sensitive amylopectin/azure substrate in $50 \mathrm{~mm}$-sodium acetate buffer, $\mathrm{pH} 6$, and $50 \mathrm{~mm}$-Tris/ $\mathrm{HCl}$ buffer, $\mathrm{pH} 8(2 \mathrm{ml})$. The reaction was initiated by adding cells or enzyme extract $(1 \mathrm{ml})$. After incubation at $30^{\circ} \mathrm{C}$ for up to $12 \mathrm{~h}$, samples were centrifuged and the $A_{610}$ was recorded. Cellulase (EC 3.2.1.4) activity was assayed similarly using cellulose/azure $\left(10 \mathrm{mg} \mathrm{ml}^{-1}\right)$ as substrate. $\beta$-Glucuronidase (EC 3.2.1.31) activity was measured using $p$-nitrophenyl glucuronide $\left(1 \mathrm{mg} \mathrm{ml}^{-1}\right)$ in either 50 mm-sodium acetate buffer, $\mathrm{pH} 6$, or $50 \mathrm{~mm}$-Tris/ $\mathrm{HCl}$ buffer, $\mathrm{pH}$. The reaction was started by adding cells or enzyme extract $(1 \mathrm{ml})$. Glutamate dehydrogenase (EC 1.4 .1 .3$)$ activity was assayed in a mixture containing $0 \cdot 1 \mathrm{ml}$ of neutralized $0.15 \mathrm{M}$-2-oxoglutarate, $0.4 \mathrm{ml}$ of $0.5 \mathrm{~mm}-\mathrm{NADH}$ (or NADPH) and $0.1 \mathrm{ml}$ of $1 \mathrm{M}-\mathrm{NH}_{4} \mathrm{Cl}$ (all solutions prepared in $100 \mathrm{mM}-\mathrm{KH}_{2} \mathrm{PO}_{4} / \mathrm{K}_{2} \mathrm{HPO}_{4}$ buffer, $\mathrm{pH} 7 \cdot 6$ ); the reaction was started by adding enzyme 0022-1287/79/0000-8499\$02.00 (C) 1979 SGM 

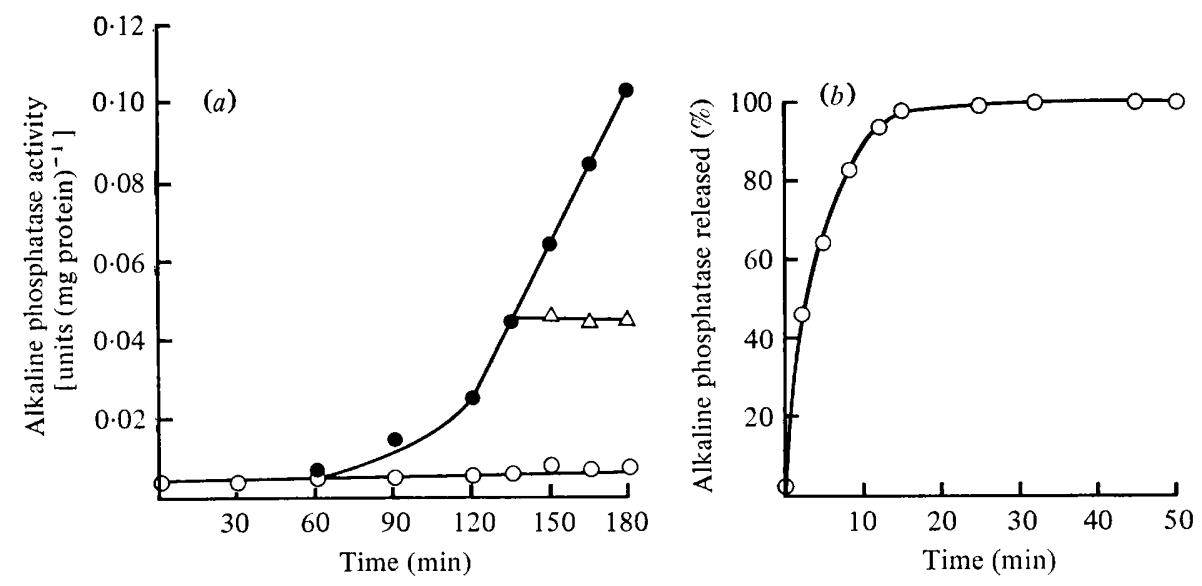

Fig. 1. Derepression and release of alkaline phosphatase in Rhizobium leguminosarum WU235. (a) At intervals, samples were removed from phosphate-rich $(O)$ and phosphate-deficient $(\bullet)$ cultures and assayed for alkaline phosphatase activity. After $135 \mathrm{~min}$, the phosphate-deficient culture was halved and inorganic phosphate $(10 \mathrm{mM})$ was added to one culture $(\triangle)$; the other culture served as the phosphate-deficient control. (b) Phosphatase-derepressed cells were treated with lysozyme/EDTA. At intervals, $1 \mathrm{ml}$ samples were removed and filtered (Millipore, $0.45 \mu \mathrm{m}$ pore size) and the filtrates were assayed for alkaline phosphatase activity $(O)$.

extract $(0 \cdot 25 \mathrm{ml})$ and the change in $A_{340}$ was recorded. Phosphodiesterase (EC 3.1.4.1) activity was measured using $p$-nitrophenyl thymidine phosphate $\left(1 \mathrm{mg} \mathrm{ml}^{-1}\right)$ as substrate in either $50 \mathrm{~mm}$-sodium acetate buffer, pH 6, or $50 \mathrm{~mm}$-Tris/HCl buffer, $\mathrm{pH} 8$.

The following enzymes were assayed by published methods: $5^{\prime}$-nucleotidase (EC 3.1.3.5), $3^{\prime}$-nucleotidase (EC 3.1.3.6) and inorganic pyrophosphatase (EC 3.6.1.1) (Neu, 1967); cyclic phosphodiesterase (EC 3.1.4.d) and acid phosphatase (EC 3.1.3.2) (Neu \& Heppel, 1964); alkaline phosphatase (EC 3.1.3.1) (Torriani, 1960); protease (Semets et al., 1973); deoxyribonuclease (EC 3.1.4.5) (Kunitz, 1950); ribonuclease (EC 3.1.4.22) (Burt \& Cazin, 1976); polygalacturonic acid trans-eliminase (Pickaver, 1977).

Cell disintegration. Bacteria were broken at $4{ }^{\circ} \mathrm{C}$ in $100 \mathrm{mM}-\mathrm{KH}_{2} \mathrm{PO}_{4} / \mathrm{K}_{2} \mathrm{HPO}_{4}$ buffer, $\mathrm{pH} 7 \cdot 6$, in a French pressure cell at $20 \mathrm{MPa}$; the crude extract was not centrifuged.

Polyacrylamide gel electrophoresis. Gels were run at $4{ }^{\circ} \mathrm{C}$ using the system described by Ornstein \& Davis (1962). Alkaline phosphatase activity on acrylamide gels was detected using Fast Blue RR salt and $\alpha$-naphthyl acid phosphate in $0.6 \%$ borax. Gels were stained for protein with Coomassie Brilliant Blue G250.

\section{RESULTS AND DISCUSSION}

\section{Extracellular proteins}

Samples of cell-free culture supernatant taken at different times throughout the growth of $R$. leguminosarum WU163 and WU235 growing on yeast extract/mannitol broth or glutamate/minimal salts containing glycerol, glucose or mannitol, were assayed for extracellular enzyme activity. There was no detectable acid, neutral or alkaline protease activity, acid or alkaline $\alpha$-amylase, cellulase, phosphatase, phosphodiesterase, $\beta$-glucuronidase or polygalacturonic acid trans-eliminase in any supernatant. Furthermore, when samples of culture supernatants taken from both minimal and broth media at various phases of the growth cycle were concentrated 20 -fold by ultrafiltration and then examined by polyacrylamide gel electrophoresis at $\mathrm{pH} \mathrm{8.9,} \mathrm{no} \mathrm{protein} \mathrm{bands} \mathrm{were} \mathrm{detected} \mathrm{for} \mathrm{the} \mathrm{glucose/gluta-}$ mate or mannitol/glutamate media, and the only protein present in cultures grown on yeast extract/mannitol broth was also present in uninoculated control medium.

Thus, these two strains of $R$. leguminosarum do not produce extracellular proteins. Furthermore, since no hydrolytic enzyme activity was detected with intact cells, it seems that these strains do not have hydrolytic enzymes on their outer cell surface. 


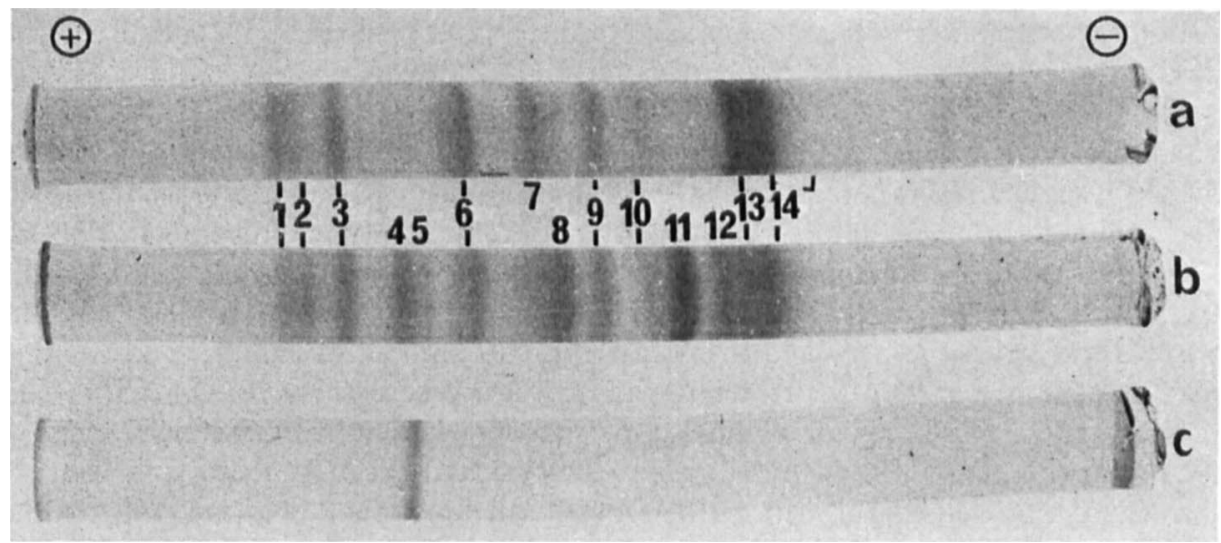

Fig. 2. Polacrylamide gel electrophoresis of periplasmic proteins released from phosphate-rich (a) or phosphate-deficient (b) Rhizobium leguminosarum WU235. The position of the alkaline phosphatase activity is shown in $c$.

\section{Periplasmic proteins}

Since there was no evidence either for the release of hydrolytic enzymes or for their association with the cell surface, we examined $R$. leguminosarum for the presence of periplasmic enzymes. In several other Gram-negative organisms alkaline phosphatase has a periplasmic location (Neu \& Heppel, 1964; Done et al., 1965; Cheng et al., 1970) and provides a convenient marker enzyme for following the release of this group of proteins. Rhizobium leguminosarum WU235, grown in the normal phosphate-rich glutamate medium with mannitol or glucose, produced only a very low basal activity of alkaline phosphatase. Cells grown in such a medium to mid-exponential phase $\left(A_{600}=1 \cdot 0 ; 700 \mu \mathrm{g}\right.$ protein $\left.\mathrm{ml}^{-1}\right)$ became derepressed for alkaline phosphatase 45 to $90 \mathrm{~min}$ after centrifugation and resuspension in a phosphate-free medium. The variation in derepression time was probably due to carry over of $\mathrm{P}_{\mathrm{i}}$. After this time, activity increased rapidly (Fig. 1a). The addition of $\mathrm{P}_{\mathrm{i}}$ $(10 \mathrm{mM})$ to derepressed cells resulted in rapid repression (Fig. 1a), suggesting a typical short-lived bacterial mRNA for this enzyme. Centrifugation of phosphate-starved cells produced a pellet containing $99.8 \%$ of the total alkaline phosphatase activity. Since phosphate esters are usually poorly transported into bacterial cells, some indication of the location of the phosphatase could be achieved by comparing the levels of enzymic activity of toluene-treated and untreated derepressed cells (Glenn \& Coote, 1975). Bacteria made permeable with toluene had identical activities of alkaline phosphatase to untreated bacteria [0.105 units (mg protein $\left.)^{-1}\right]$, suggesting that the enzyme was accessible to the substrate and presumably, therefore, external to the cytoplasmic membrane.

Various methods were employed in attempts to release the enzyme from the cells. Osmotic shock (Neu \& Heppel, 1964) released less than $5 \%$ of the activity and ionic elution with a variety of salts (Glenn \& Mandelstam, 1971) released less than $3 \%$ of the activity. However, treatment of phosphate-starved cells in Tris/ $\mathrm{HCl}$ buffer $(30 \mathrm{mM}), \mathrm{pH} 8 \cdot 0$, containing sucrose $(20 \%, \mathrm{w} / \mathrm{v})$, lysozyme $\left(500 \mu \mathrm{g} \mathrm{ml}^{-1}\right)$ and EDTA $(1 \mathrm{mM})$ released the alkaline phosphatase into the supernatant. (Lysozyme at $500 \mu \mathrm{g} \mathrm{ml}^{-1}$ gave the maximum release of alkaline phosphatase activity.) Enzyme release following treatment of bacteria with lysozyme was rapid for the first $10 \mathrm{~min}$ and essentially complete within $15 \mathrm{~min}$ (Fig. $1 \mathrm{~b}$ ). There was some day-to-day variation in the extent of enzyme release with this procedure but it was usually 75 to $100 \%$.

The sequence of addition of lysozyme and EDTA to the cells affected the amount of phosphatase released. When EDTA was added before lysozyme, 20\% less enzyme was released. The age of the cells also affected the amount of enzyme released by lysozyme/ 
EDTA treatment. Cells in the initial depression phase (Fig. $1 a$ ) released some 75 to $100 \%$ of cell-bound phosphatase, whereas cells subjected to longer periods of phosphate starvation released less enzyme, until after $24 \mathrm{~h}$ starvation only $25 \%$ of the cell-bound enzyme was released.

Periplasmic proteins released from phosphate-depleted $R$. leguminosarum WU163 and WU235 by lysozyme/EDTA treatment were concentrated by ultrafiltration and subjected to polyacrylamide gel electrophoresis. A consistent pattern of 14 protein bands was observed (Fig. 2b). Gels stained for alkaline phosphatase (Fig. $2 c$ ) showed that only band 4 had this activity, and no electrophoretically distinguishable isoenzymes were detected. The reproducibility of the protein pattern and the relatively small number of bands is consistent with a specific release of periplasmic proteins without release of cytoplasmic proteins. This is supported by the lack of detectable glutamate dehydrogenase activity in concentrated periplasmic protein extracts $\left(1.04 \mathrm{mg} \mathrm{ml}^{-1}\right)$ prepared by lysozyme/EDTA treatment. Glutamate dehydrogenase was detected in cell extracts produced by French pressure cell treatment. Activity was greatest with $\mathrm{NADH}$ as cofactor $\left[40.9 \mathrm{nmol} \mathrm{min}^{-1}\right.$ (mg protein) $\left.{ }^{-1}\right]$ but

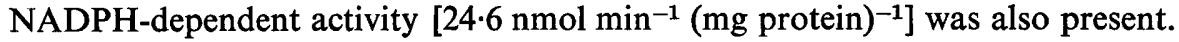

Periplasmic proteins were also released when cells grown in a phosphate-rich mannitol/ glutamate medium were treated with lysozyme/EDTA. When these proteins were examined by polyacrylamide gel electrophoresis, bands $4,5,8$ and 11 were absent (compare Fig. 2a,b). Variation in the carbon source for growth (glucose, mannitol or glycerol) had no major effect on the electrophoretic pattern of the proteins released by lysozyme/EDTA treatment. These observations suggest that, in addition to alkaline phosphatase (band 4), synthesis of proteins 5,8 and 11 is also repressed by inorganic phosphate.

Attempts have been made to identify some of the periplasmic proteins. In other Gramnegative bacteria many of the periplasmic proteins are phosphatases or nucleotidases (Neu $\&$ Heppel, 1965). We have been unable to detect any $5^{\prime}$-nucleotidase, $3^{\prime}$-nucleotidase, acid hexose phosphatase, acid phosphatase, phosphodiesterase, deoxyribonuclease, ribonuclease, protease, $\alpha$-amylase, $\beta$-glucuronidase or polygalacturonic acid trans-eliminase activity in the periplasmic protein extracts. We have, however, demonstrated cyclic phosphodiesterase activity [11 nmol $P_{1} \min ^{-1}\left(\mathrm{mg}\right.$ protein) $\left.{ }^{-1}\right]$ and pyrophosphatase activity [ $90 \mathrm{nmol} \mathbf{P}_{1}$ min $^{-1}$ $\left.(\mathrm{mg} \text { protein })^{-1}\right]$ in addition to the alkaline phosphatase.

Therefore, although we have shown that there are a group of periplasmic proteins in $R$. leguminosarum, we have only been able to identify three enzyme activities - cyclic phosphodiesterase, pyrophosphatase and alkaline phosphatase. The identity of the other proteins is unclear at present though one possibility is that some of them, including the phosphate-repressible proteins 5, 8 and 11 , may be solute-binding proteins.

This work was funded by the Australian Research Grants Committee. We wish to thank Mr B. Hewitt and Ms Jane White for technical assistance.

\section{REFERENCES}

Brown, C. M. \& Dilworth, M. J. (1975). Ammonia assimilation by Rhizobium cultures and bacteroids. Journal of General Microbiology 86, $39-48$.

BurT, W. R. \& Cazin, J. (1976). Production of extracellular ribonuclease by yeasts and yeast-like fungi, and its repression by orthophosphate in species of Cryptococcus and Tremella. Journal of Bacteriology 125, 955-960.

Cheng, K. J., Ingram, J. M. \& Costeron, J. W. (1970). Alkaline phosphatase localization and spheroplast formation of Pseudomonas aeruginosa. Canadian Journal of Microbiology 16, 1319-1324.
Done, J., Shorey, C. D., Loke, J. P. \& PollaK, J. K. (1965). The cytochemical localization of alkaline phosphatase in Escherichia coli at the electron-microscope level. Biochemical Journal 96, 27-28c.

GlenN, A. R. (1976). Production of extracellular proteins by bacteria. Annual Review of Microbiology 30, 41-62.

GlenN, A. R. \& Coote, J. G. (1975). Cytochemical studies on alkaline phosphatase production during sporulation in Bacillus subtilis, Biochemical Journal 152, 85-89.

GlenN, A. R. \& Mandelstam, J. (1971). Sporula- 
tion in Bacillus subtilis 168. Comparison of alkaline phosphatase from sporulating and vegetative cells. Biochemical Journal 123, 129-138.

Godfrey, C. A. \& Dilworth, M. J. (1971). Haem biosynthesis from $\left[{ }^{14} \mathrm{C}\right]-\delta$-aminolaevulinic acid in laboratory-grown and root nodule Rhizobium lupini. Journal of General Microbiology 69, 385390.

Hofsten, B. V. (1975). Topological effects in enzymatic and microbial degradation of highly ordered polysaccharides. In Symposium on Enzymatic Hydrolysis of Cellulose, An lanko, Finland.

KunITz, M. (1950). Crystalline deoxyribonuclease. I. Isolation and general properties. Journal of General Physiology 33, 349-362.

Neu, H. C. (1967). The 5'-nucleotidase of Escherichia coli. Journal of Biological Chemistry 242. 3896-3904.

NeU, H. C. \& HePpel, L. A. (1964). On the surface localization of enzymes in Escherichia coli. Biochemical and Biophysical Research Communications 17, 215-219.

NeU, H. C. \& HePpel, L. A. (1965). The release of enzymes from Escherichia coli by osmotic shock and during the formation of spheroplasts. Journal of Biological Chemistry 240, 3685-3692.
Nossal, N. E. \& Heppei, L. A. (1966). The release of enzymes by osmotic shock from Escherichia coli in exponential phase. Journal of Biological Chemistry 241, 3055-3062.

OrnsteIn, L. \& Davis, B. (1962). Disc Electrophoresis. Rochester, N.Y.: Distillation Products Industries.

Pickaver, A. H. (1977). Diagnostic agar plate techniques for testing pectinase producing bacteria can give false negative results. FEMS Microbiology Letters 2, 105-107.

Pollock, M. R. (1962). Exoenzymes. In The Bacteria, vol. 4, pp. 121-178. Edited by I. C. Gunsalus \& R. Y. Stanier. London and New York: Academic Press.

Semets, E. V., Glenn, A. R., May, B. K. \& Elliott, W. H. (1973). The accumulation of messenger RNA specific for extracellular protease in Bacillus subtilis 168. Journal of Bacteriology 116, 531-534.

TORRIANI, A. (1960). Influence of inorganic phosphate in the formation of phosphatases by Escherichia coli. Biochimica et biophysica acta 38, 460479. 